\title{
Raiva bovina e linhas de conduta
}

\begin{abstract}
No meio veterinário, por vezes, deparamo-nos com certos posicionamentos ou condutas de consenso não apropriados. $O$ comportamento de um grande número de veterinários em relação à ocorrência da raiva em bovinos e a possibilidade desses animais a transmitirem ao homem constitui um exemplo dessa assertiva. Frente a um surto de doença em bovinos que curse com sintomatologia de origem nervosa, via de regra, o veterinário suspeita ou faz diagnóstico de raiva. Em muitos casos, a suspeita ou o diagnóstico estão corretos, já que a raiva transmitida por morcegos é uma das doenças mais frequentes nessa espécie no Brasil. Por outro lado, no país ocorrem outras doenças que afetam o sistema nervoso e que também são responsáveis por grandes mortandades em bovinos. Isto posto, é fundamental que a atuação dos veterinários seja correta para possibilitar o diagnóstico exato.
\end{abstract}

\section{A RAIVA BOVINA E O VETERINÁRIO DE CAMPO}

Em se tratando de um surto de enfermidade que curse com sinais clínicos de origem nervosa, os veterinários que trabalham no campo adotam uma das seguintes condutas:

1. Determinam que o animal seja sacrificado e enterrado, sem contudo, fazerem exame clínico ou neurológico.

2. Após morte natural ou o sacrifício, determinam que se seccione a cabeça do animal e a enviam ou orientam o proprietário, para que a envie a alguma repartição pública ou universidade "para diagnóstico de raiva”; e entretanto não procedem a necropsia.

3. Enviam todo o cadáver ou ainda um animal enfermo a um órgão público, para estudo da possível causa mortis.

4. "Abrem" o animal, após o sacrifício ou morte natural, e retiram fragmentos de órgãos das cavidades torácica e abdominal, os acondicionam em recipientes com gelo e/ou formalina e os remetem para o laboratório. Não retiram, todavia, fragmentos do sistema nervoso central.

5. Procedem como no ítem anterior, porém tomam o cuidado de retirar e remeter também porções do sistema nervoso central.

Ressalta-se que muitos veterinários não fazem exames clínicos, muito menos neurológico no animal; alguns colegas sequer se aproximam do bovino enfermo ou morto, por medo de "pegarem raiva".

Em vários municípios das Regiões Sudeste e Nordeste, tão logo o animal mostre ataxia dos membros posteriores, o proprietário, com ou sem conhecimento do veterinário manda que o animal seja abatido ( às vezes, pelo açougueiro local !) e a carne utilizada em sua propriedade ou comercializada normalmente.
Comentários. O ideal, para se chegar ao diagnóstico etiológico, é o procedimento adotado no ítem 3 , desde que o bovino seja enviado para um setor de patologia com profissionais experientes em diagnóstico. $O$ patologista procede a necropsia, colhe fragmentos para exames histopatológicos, bacteriológicos, virológicos, toxicológicos, imunofluorescência para raiva, conforme o caso. Na impossibilidade de transportar todo o animal ou cadáver, a melhor opção é o ítem 5 . Cuidados básicos, entre os quais a utilização de luvas, eliminam o risco de infecção. Em parte dos casos é fundamental que o patologista se desloque até o local do surto, a fim de fazer um levantamento epidemiológico completo e/ou inspecionar as pastagens.

Já a prática do abate e consumo de carne de bovinos com distúrbios de origem nervosa, é óbvio, deve ser firmemente rejeitada pelo veterinário; entretanto, essa prática fornece importante dado no que se refere às relações epidemiológicas entre o bovino raivoso e o homem. Partindo-se do fato que a raiva bovina é muito frequente em nosso país e que o abate de animais enfermos ocorre em muitas regiões, seria de se esperar um significativo número de casos de raiva em humanos, transmitida pelos bovinos. Porém, até onde sabemos, não há um só caso de raiva em humanos, no Brasil, comprovadamente oriunda dos bovinos. Casos de raiva em humanos, dados as suas características e manifestações mórbidas, não passariam facilmente despercebidos. Verificamos a literatura internacional e, nos últimos 30 anos, não encontramos nenhum caso comprovado de raiva humana transmitida pelo bovino.

$O$ pretenso grande risco do homem vir a infectar-se a partir do bovino seria ainda maior, se considerarmos que qualquer animal raivoso pode estar eliminando o vírus, via saliva, 4 a 5 dias antes de ter demonstrado qualquer sinal clínico. 
Nesse ponto, torna-se claro que não há justificativa para não se examinar um bovino, apenas porque suspeita-se que ele possa estar infectado pelo vírus rábico. Primeiramente porque basta que se utilizem luvas no exame desses animais. Em segundo lugar, porque, por esse raciocínio, nenhum bovino deveria ser examinado, de vez que a raiva pode mimetizar várias doenças, ou ainda porque qualquer animal poderia estar eliminando o vírus sem mostrar sintomas.

\section{A RAIVA BOVINA E O ENSINO UNIVERSITÁRIO}

É natural que os veterinários, em geral, tenham a conduta errônea previamente descrita com relação à raiva bovina, pois o assunto não é abordado convenientemente na maioria das universi-dades. Os procedimentos e as formas de condutas ensinados aos acadêmicos, via de regra, são calcados em interpretações errôneas. Temos verificado no dia-a-dia, situações como os que se seguem:

1. Alunos são aconselhados por professores a se vacinarem, não sem antes serem "informados" dos riscos que correm, apenas porque passaram perto de um bovino raivoso.

Comentários. O "conselho" baseia-se no fato de que o vírus pode infectar por via olfatória, o que é uma verdade incontestável. Todavia, os que preconizam essa conduta, esquecem de levar em conta em que condições esse modo de transmissão se verifica. Fora do laboratório, por via olfatória, a infeccão pelo vírus rábico só ocorre nas cavernas de morcegos, onde é elevada a concentração de vírus rábico no ar. Portanto nessa situação, esse risco pode ser descartado, a menos que tenhamos em mente, transportar o bovino para uma caverna de morcego, e lá necropsiá-lo. Em função disso acadêmicos tem sido expostos a riscos, de fundo alérgico, desnecessários. Há que se computar também o forte abalo psicológico que sofrem alguns acadêmicos, digamos, mais influenciáveis.

2. A vacinação também é, às vezes, aconselhada quando há contacto da mão do ser humano com a pele de um bovino raivoso ou suspeito de sê-lo.

Comentários. A possibilidade de infecção por essa forma também pode ser descartada. Nesse ponto, é fundamental recordarmos que o homem e o gambá são os mamíferos mais resistentes à infecção pelo vírus rábico. Além disso, é importante levar em conta que não se pode comparar o grau de infectividade do vírus rábico "de rua" (raiva canina) com a do vírus oriundo dos bovinos.

3. Ensina-se em alguns bancos acadêmicos que bovinos suspeitos de estarem acometidos de raiva não devem ser necropsiados, em hipótese nenhuma. Os animais suspeitos deveriam ter a cabeça removida e enviada para "exames de raiva" (imunofluorescência e inoculação em camundongo) e o cadáver sumariamente enterrado.

Comentários. É de conhecimento geral, do ponto de vista clínico, o jargão "tudo que é atípico, pode ser típico para raiva". Por esse raciocínio, todo bovino enfermo, ou mesmo sadio, seria suspeito de raiva, por isso não deveria ser necropsiado.

Outras doenças que cursam com sintomatologia nervosa em bovinos como a polioencefalomalácia, a encefalite por herpesvírus, o botulismo epizoótico e certas intoxicações por plantas, só para citar algumas enfermidades descritas em bovinos no Brasil, jamais teriam sido diagnosticados.

4. Ainda como argumento para a não-realização de necropsia mencionase que o vírus pode infectar pelo sangue, fezes e leite.

Comentários. Essa assertiva, também, ao nosso ver, não se justifica, já que, embora essas secreções raramente possam conter o vírus, elas não tem qualquer importância na difusão da doença. Isso sem considerar-se que seria necessário, para a contaminação, que o veterinário não usasse luvas e tivesse um ferimento pelo qual o vírus pudesse alcançar o fuso muscular, ou que esfregasse essas secreções nas mucosas.

\section{CONSIDERAÇÕES FINAIS}

A intenção desse artigo é destacar que certas condutas relacionadas à raiva bovina não se justificam, porque dificultam ou impossibilitam o diagnóstico e controle de outras doenças. Somos da opinião que os veterinários e acadêmicos devem, sim, se proteger dos riscos da infecção por vírus rábico ou por qualquer outro agente patogênico. A utilização de luvas nos exames clínicos e necropsias é uma medida eficaz e barata de proteção e está ao alcance de todos. Vacinações profiláticas no caso de profissionais expostos ao vírus rábico, sobretudo ao vírus de rua, podem ser aconselhadas, sem, entretanto, esquecermos os riscos de hipersensibilidade. Em alguns países vacina-se com antígenos purificados, como aqueles preparados com embriões de pato, medida que diminui acentuadamente a possibilidade de reações alérgicas.

Por outro lado, se não utilizarmos os conhecimentos científicos à luz do raciocínio lógico, corremos mais que o risco de infecção, o risco de voltarmos à Idade Média.

Paulo Vargas Peixoto

Departamento de Epidemiologia e Saúde Pública

Universidade Federal Rural do Rio de Janeiro

23851-970 Seropédica, Rio de Janeiro. 